\title{
Evaluation of the Cow's Fertility using Artificial Insemination in Sulaimani Region from 1999 to 2002
}

\author{
Faraidoon A.S.M.Amin ${ }^{I}$
}

A total number of cows artificially inseminated and became pregnant in Sulaimani region during 1999-2002 were 36952 and 15020 respectively. The year 2001 showed the highest numbers of those inseminated and became pregnant, while year 1999 showed the lowest numbers, $1039(5.197 \%)$.

The overall mean of fertility rate was $40.647 \%$ however the total number of cows those treated with hormone was 8101 ( $21.92 \%)$.

In August 2002 the total number of cows artificially inseminated was 2070, Sharazoor center performed the highest numbers followed Rania center then Kalar and Chamchamal, while Sulaimani center performed the lowest numbers. The fertility rate after GnRH treatment was found to be $(74.71 \%)$ while the fertility rate of cows during August 2002 for all locations was 53.87\%

The objectives of this study was to the evaluate the reproductive performance of dairy cattle in Sulaimani region throughout the evaluation of the status of the process of Artificial Insemination from year 1999 up to 2002.

$$
\text { " تقييم الكفاعة التناسلية لأبقار الحليب في منطقة السلبيانية }
$$

الخلاصة

$$
\begin{aligned}
& \text { الهدف من اجراء هذا البحث هو لتقييم الكفاءة التتاسلية لابقار الحليب في منطقة السليمانية }
\end{aligned}
$$

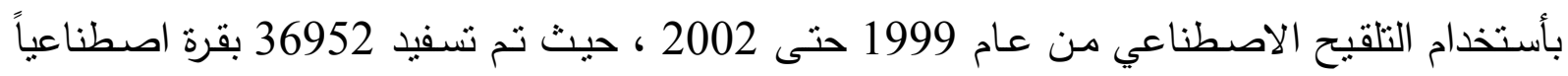

$$
\begin{aligned}
& \text { بواسطة الجس عن طريق المستقيم، بلغ مجموع الابقار التي اصبحت حاملا } 15020 .
\end{aligned}
$$

\footnotetext{
${ }^{\mathrm{I}}$ Department of Clinic \& Surgery. College of Veterinary Medicine.

University of Sulaimani. Sulaimani- Iraq
}

$$
\text { "فرع الكلينك والجراحة - كلية الطب البيطري - جامعة السليمانية- السليمانية- العراق . }
$$


أظهرت نتائج الدراسة أكبر نسبة من الأبقار المسفدة والحامل عام 2001 بينما كان أقل نسبة في عام 1999. حيث بلغت نسبة الخصوبة 40.647 \% بينما كان عدد الابقار التي تمت معالجتها بالهرمونات 8101

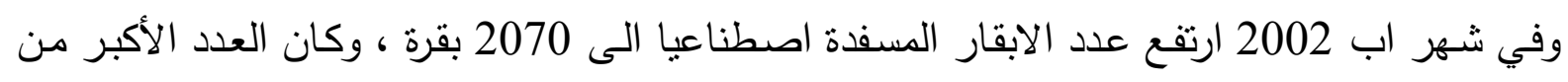
هذه الابقار في منطقة شهرزور وجاءت منطقة رانية بالمرنبة الثانية وكلار وجمجمال في المرتبة الثالثة

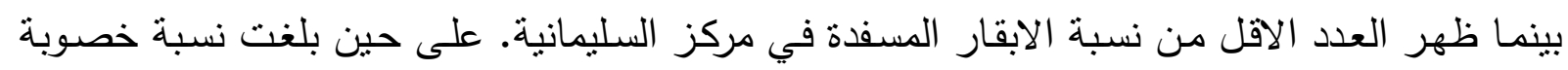

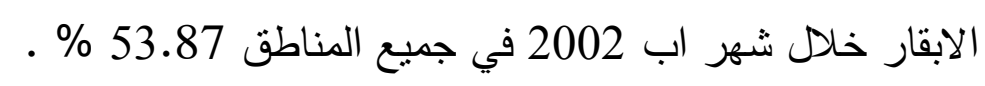

يستتج من هذة الدراسة إن خصوبة الأبقار بعد العلاج بهورمون

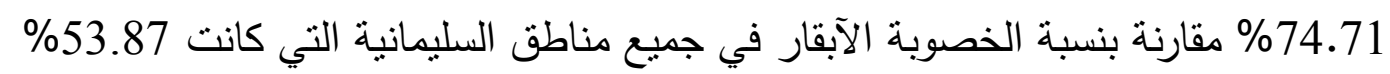

\section{Introduction}

Friesian dairy cattle breed was introduced in to Iraq to be raised a pure breed and to grade up the indigenous cattle in an attempt to increase the output of milk yield in this country.

Information of imported friesian bulls to Iraq was therefore of great value for the future of dairy cattle improvement plans ${ }_{(1,2)}$. Furthermore ${ }_{(3,4)}$ reported that the pregnancy rate can be influenced by temperature and stress. However (5) found that animals susceptible to environmental factors effects on serum luteinizing hormone.

Therefore this study was designed to evaluate the reproductive performance of cows from different location according to determine the pregnancy rate after hormonal treatment with Gonadotropin releasing hormone GnRH ( Fertagyl).

\section{Materials and Methods}

The process of artificial insemination had widely and successfully achieved in region and other neighboring locations of artificial insemination centers by FAO during 1999-2002.

The number of cows artificially inseminated in 1999 were (1039), in2000 (7965), in 2001 (15869) and in 2002 were (12079).

The process of A.I that had been used in this program was frozen method. Frozen semen was obtained from the artificial insemination centerin Abu-Graib at Baghdad. This material was distributed to five A.Icenters at sulaimani region namely: sulaimani rania chamchammal : sharazoor and kalar . 
33team workers were allocated to cover most of the sulaimani region for artificial insemination centers by FAO from jun 1999 up to October 2002. This study was dealing on artificial insemination service from June 1999 up to October 2002 using individual records of each cow obtained from FAO suboffice in Sulaimani of cows artificially inseminated during different years and the numbers of these retested for pregnancy by rectal palpation and become pregnant for different sites .

During this inverstigation the effects of stress factor and hormonal treatment with fertagyl ((intervet) $0.5 \mu \mathrm{g}$ i.m by injecting on the day of A.I) and the years on the rate of fertility were also considered.

The fertility rate of a cow this study depended on the pregnancy diagnosis results.

Data of different locations of artificial insemination centers were analyzed by using chi-square analysis and the results were recorded ${ }^{(6)}$.

\section{Results}

In the Sulaimani region, there was a gradual increasing in the number of artificially inseminated cows during the period of 1999-2002 (Table, 1).

The total numbers of cows artificially inseminated and became pregnant during 1999-2002 were 36952 and 15020 respectively, which differ during different years studied (Table, 1).

The year 2001 showed the highest numbers of those inseminated and became pregnant, while year 1999 showed the lowest numbers. However the overall mean of fertility rate (pregnancy rate) was $40.647 \%$, in which was significantly $(\mathrm{p}<0.05)$ differ during different years studied .The fertility rate during 1999 and 2000 was significantly lower than those recorded during 2001 and 2002.

The total number of cows tested for pregnancy was 20102 (Table-1) which differs during different periods. However the pregnancy percentage of the total pregnancy cows tested was $74.71 \%$, this ratio was significantly $(\mathrm{p}<0.05)$ lower than recorded in year 1999 compared with other years studied. The total number of cattle those treated with hormones was 8101. The ratio of the hormonal treated cows of the total artificially inseminated was $21.92 \%$, this ratio was significantly $(\mathrm{p}<0.05)$ higher in 1999 compared with other years studied.

In August 2002 the total numbers of cows artificially inseminated was 2070 (Table-2), Sharazoor center performed the highest numbers follow Rania center then Kalar and Chamchamal, while Sulaimani center performed the lowest numbers. However the fertility rate of cows during August 2002 for all locations was $53.87 \%$ which was significantly $(\mathrm{p}<0.05)$ differ due to different location centers, Kalar center revealed the highest ratio $(80.90 \%)$, while chamchamal 
center deducted the lowest ratio. However the ratio of the pregnancy test due to the total numbers of cows artificially inseminated was $78.91 \%$, which was significantly $(\mathrm{p}<0.05)$ differ due to different locations viz: Kalar center performed significantly better than other locations, Chamchamal deducted the lowest ratio

(Table-2).

The total number of hormonal treated cows was 1876 , while the ratio of the hormonal treated animals to the total numbers of cows artificially inseminated was $90.63 \%$, which wasn't differ due to different location center. 
Iraqi Journal of Veterinary Medicine Vol. 30, No. 1, 2006 


\section{Discussion}

A progress in the number of artificially inseminated cows with time during the period 1999-2002 might be due to an increase in the number of cows in these 
areas and more experience and facilities of the team workers, which was in contrast with the findings of (7). However the fertility rate of this study was $40.647 \%$, which was similar (40\%) to that found by $(8)$.

In Brazil using Zebu herd and lower than of F1 crosses (Indo Brazil \& holstein) which recorded $37 \%$. Other workers showed higher fertility rate in different countries $_{(9)}$, in Iraq $(10)$ in UK ${ }_{(11)}$ in Brazil and Iraq $(7)$. Year of study had significant effect on fertility rate, these results were in agreement with those found $b_{(7)}$. These differences could be due to the effects of heat stress be cause $_{(12,4)}$ mentioned that the heat stress have a direct adverse effect of increased body temperature and hence uterine temperature leading to fertilization failure or due to an indirect effect consequent to altered endocrine and uterine function, also manage mental effect such as feeding regime have role in this variation be cause $^{(13,14)}$ showed that the seasonal effect on fertility may have an interaction with the levels and quality of feed.

However the pregnant cows of those tested for pregnancy in 1999 was significantly $(\mathrm{p}<0.05)$ lower in 1999 compared with the other years studied, this could be attributed to the activity of the team workers and their experience ${ }_{(15)}$.

The total percentage of the cows treated with hormones was $21.92 \%$ which was significantly differ due to different periods studied .The injection of Fertagyl on the day of A.I in order to hasten ovulation and to improve conception rate through its effects on LH release ${ }_{(16)}$. In 1999 high ratio of hormonal treated cows was conducted this could be due to the low numbers of cows inseminated at that time and the project was at it's beginning.

In general, Kalar center showed higher performance in it's work compared with other locations, these differences could be attributed to many factors such as number of animals spread, the activities and facilities of the team workers of the centers. However ${ }_{(17)}$ showed the same trend but ${ }_{(18)}$ showed no differences in the reproductive performance of different location.

Therefore it could be concluded that the fertility rate, the diagnosis of pregnancy ratio and hormonal treated cows ratio differ with time and the site of artificial insemination centers in Sulaimani regions.

\section{References}

1. Juma KH and Dessouky F (1969).Deterioration in some semen characters of Friesian bulls raised in Iraq. Trop. Agri-Trin 46: 63-68.

2. Al-Badry KI (1997). The effect of place of origin on the reproductive performance of Friesian bulls under Iraqi environments. TheVeterinarian ; 6,7 (1) : 77-82. 
3. Johanson EJ and Branton C (1953). Effect of seasonal climatic certain physiological reactions semen production and fertility of dairy bulls. J. Dairy. Sci; 36: 934-938.

4. Ali, J.B,Jawad NMA and Pant HC (1983). Effects of Summer heat stress on the fertility of Friesian Cows in Iraq. World Review of Animal Production, 19;3;75-80.

5. Godfrey RW; Lunstra DD; Jenkins TG; Beradinelli JG; Guthrie MJ; Neuendroff DA. ; Long CR and Randel RD (1990).

Effect of the season and location on semen quality and serum concentration of luteinizing hormone and testosterone in Brahman and herford bulls. J. Anim.Sci, 68: 734-749.

6. Steel RGD. and Torrie JH. (1980). Principles and Procedures of Statistics. McG raw - Hill, New York. U.S.A.

7. Baker SS; Aziz MA and Mousa HA. (1999). The role of improper use of artificial insemination on infertility and abortion in cow in Basrah province - Iraq. Microbiological study. The Veterinarian; 9 (3): $12-19$.

8. Escobar F-J, Fernandez - Baca, S.; Galina CS; Berrue cos J M and Saltiel A (1982) Estudiodel in tervale entre partos en bovines ductorers de carneen una explotacion ael altiplano yotra de la a tropical humeda. Veterinaria Mexsico, 13, 53 (Summary).

9. Dessouky F and Juma K H; (1973). Infertility problems among cows and buffalos's in Iraq . Indian J. Anim . Sci ; 43 : 187-192

10. Al-Dahash SYA(1976). Astudy of cystic ovarian disease in cattle .Ph. D. Thesis, Bristol University, UK.

11. Vale WG.; Ohashi OM.; Ribeiro HFL. and Sousa JS (1984).

Causes and incidence of infertility and sub-fertility in Zebu crossbred cows in the Amazon region of Brazil. Vet. Med. Review; 2: 133-143.

12. Roth Z; Meiden R; Sam A; Brow -Tal R and Wolfen son D (2001). Delayed effect of heat stress on steriod production in medium size and preovulatory bovine follicles. J. Reprod. Fert; 121: 745-751.

13. Whitmore HL; Tyler WJ and Casida LE (1974).

Effect of early post partum breeding in dairy cattle . J. Anim. Sci; 38 : 339-341.

14. ZaKari AY, MoloKwu ECI., OSOri DIK(1981). Effects of Rectal and ambient temperatures and humidity on conception rates. Theriogenology, 16;331-337.

15. Peters A R and Ball PJH (1987). Reproduction in Cattle. $2^{\text {nd }}$ ed. , Butterworth and Co. Ltd. London.

16. Amin $\operatorname{FAM}(2001)$. Clinical and abattoir study of reproductive Problems in local breed cows in Sulaimani district. M.V.Sc, thesis, 
University of Sulaimani-Iraq.

17. Fields MJ ;Hentges JF and Comelisse KW (1982). Aspects of Sexual development of Brahma versus Angus bulls in Florida. Theriogenology; 19: 17-22.

18. Leibenberg O and Sichting P (1971). The effect of environment and Age on semen quality and investigation of the possibilities for Improving the semen characters of bulls. Anim. Breed. Abstr; 41: 3128 . 